\title{
AN OUTLOOK OF BIOMARKERS OF EPILEPSY: IN-DEPTH REVIEW
}

\section{Authors: Ahmed Arafat, Peng Jing, Pang Nan, He Fang, Chen Chen and Yin Fei * Affiliations: Pediatrics Department, Xiangya Hospital, Central South University, China}

Epilepsy is the most common serious primary disease of the brain. Approximately $10 \%$ of people can expect to have at least one epileptic seizure during a normal lifespan, and one third of these will develop epilepsy. In our study, we report most of the potential biomarkers of epilepsy to date, according to their magnitude in either diagnosis of epilepsy or estimation of the efficacy of antiepileptic treatment through reviewing the significance of each of: pathologic High-Frequency Oscillations pHFOs, brain inflammation, Blood Brain Barrier BBB dysfunction, Traumatic Brain Injury TBI and microRNAs as a potential biomarker of epilepsy.

\section{High-Frequency Oscillations as a Biomarker in Epilepsy \\ Pathological high-frequency oscillations (pHFOs)} $(\mathrm{HFOs},>80 \mathrm{~Hz})$, identified in interictal EEG recordings seem to have the potential to line the range of epileptogenic tissue responsible for producing spontaneous seizures. interictal HFOs with spectral frequencies between 250 and $600 \mathrm{~Hz}$, termed fast ripples (FR), are found in brain areas capable of generating spontaneous seizures, including dentate gyrus, hippocampus, subiculum and entorhinal cortex. Several retrospective studies that have followed up on patients after resective surgery found that removal of tissue generating interictal pathological HFOs correlated with a good outcome. Table 1 .

In conclusion, several studies with microelectrodes conclude that fast ripples are most specific for the epileptogenic zone, but in clinical studies with macroelectrodes it is useful to include both ripples and fast ripples in the evaluation of the potential epileptogenic region.

Table 1. Studies Comparing Interictal Ripples and FRs to the Potential Epileptogenic Region

\begin{tabular}{|c|c|c|c|c|c|}
\hline Study & Subjects & Site & Electrodes & $\begin{array}{l}\text { Epileptogenicity } \\
\text { Parameter }\end{array}$ & $\begin{array}{l}\text { Conclu } \\
\text { sion }\end{array}$ \\
\hline $\begin{array}{l}\text { Bragin and } \\
\text { colleagues } \\
\text { (1999) }\end{array}$ & $\begin{array}{l}\text { Rats (KA) } \\
\text { and human }\end{array}$ & MT & Micro & $\begin{array}{l}\text { Epileptic } \\
\text { individuals and } \\
\text { seizure onset side }\end{array}$ & FRs \\
\hline $\begin{array}{l}\text { Bragin and } \\
\text { colleagues } \\
(2002)\end{array}$ & Human & MT & Micro & $\begin{array}{l}\text { Multiunit neuronal } \\
\text { synchronization }\end{array}$ & FRs \\
\hline $\begin{array}{l}\text { Bragin and } \\
\text { colleagues } \\
(2004)\end{array}$ & Rats (KA) & MT & Micro & $\begin{array}{l}\text { Side of KA } \\
\text { injection, having } \\
\text { seizures }\end{array}$ & Both \\
\hline $\begin{array}{l}\text { Staba and } \\
\text { colleagues } \\
(2004 / 2002 / 20 \\
07)\end{array}$ & Human & MT & Micro & $\begin{array}{l}\text { Seizure onset side } \\
\text { and region atrophy }\end{array}$ & FRs \\
\hline $\begin{array}{l}\text { Urrestarazu } \\
\text { and colleagues } \\
\text { (2006) }\end{array}$ & Human & $\begin{array}{l}\mathrm{MT} / \\
\mathrm{F}\end{array}$ & Macro & Seizure onset zone & FRs \\
\hline $\begin{array}{l}\text { Jacobs and } \\
\text { colleagues } \\
\text { (2008) }\end{array}$ & Human & $\begin{array}{l}\mathrm{MT} / \\
\mathrm{F}\end{array}$ & Macro & Seizure onset zone & $\begin{array}{l}\text { FRs > } \\
\text { ripples }\end{array}$ \\
\hline $\begin{array}{l}\text { Worrell and } \\
\text { colleagues } \\
\text { (2008) }\end{array}$ & Human & MT & $\begin{array}{l}\text { Micro and } \\
\text { macro }\end{array}$ & Seizure onset zone & Both \\
\hline $\begin{array}{l}\text { Jacobs and } \\
\text { colleagues } \\
\text { (2010/2009); } \\
\text { Zijlmans and } \\
\text { colleagues } \\
(2011)\end{array}$ & Human & $\begin{array}{l}\text { MT/ } \\
\text { F/P/ } \\
\text { O }\end{array}$ & Macro & $\begin{array}{l}\text { After discharges } \\
\text { and seizure onset } \\
\text { zone }\end{array}$ & Both \\
\hline $\begin{array}{l}\text { Ogren and } \\
\text { colleagues } \\
(2009)\end{array}$ & Human & MT & Micro & $\begin{array}{l}\text { Hippocampal } \\
\text { atrophy }\end{array}$ & FRs \\
\hline $\begin{array}{l}\text { Jiruska and } \\
\text { colleagues } \\
(2010)\end{array}$ & Rats (TT) & MT & Micro & Side of injection & $\begin{array}{l}\text { FRs }> \\
\text { ripples }\end{array}$ \\
\hline $\begin{array}{l}\text { Jacobs and } \\
\text { colleagues } \\
(2010)\end{array}$ & Human & $\begin{array}{l}\text { MT/ } \\
\text { F/O }\end{array}$ & Macro & Surgical outcome & $\begin{array}{l}\text { Ripples } \\
>\text { FRs }\end{array}$ \\
\hline $\begin{array}{l}\text { Luciana } \\
\text { Andrade- } \\
\text { Valença and } \\
\text { colleagues } \\
\text { (2012) }\end{array}$ & Human & MT & Both & Onset zone & both \\
\hline $\begin{array}{l}\text { Chatillon CE } \\
\text { and colleagues } \\
\text { (2013) }\end{array}$ & Human & MT & Both & SEEG segment & FRS \\
\hline $\begin{array}{l}\text { Matsumoto A } \\
\text { and colleagues } \\
\text { (2014) }\end{array}$ & Human & $\begin{array}{l}\mathrm{FC/} \\
\mathrm{TC}\end{array}$ & Macro & Onset zone & both \\
\hline $\begin{array}{l}\text { Van't } \\
\text { Klooster } \\
\text { (2015) }\end{array}$ & Human & MT & both & Surgical outcome & both \\
\hline $\begin{array}{l}\text { Francesca } \\
\text { Pizzo (2016) }\end{array}$ & Human & $\begin{array}{l}\text { Scal } \\
\text { p }\end{array}$ & Both & Scalp EEG & FRS \\
\hline
\end{tabular}

\section{Brain Inflammation as a Biomarker in Epilepsy}

The major inflammatory pathways studied for their possible contribution to epileptogenesis are the activation of the IL- $1 \mathrm{~b}$ system, COX-2 and mTOR.

Blockade of $I L-1 b$ signaling leads to prevention of seizure generalization or delays stage 5 seizure occurrence, respectively, and increases the threshold for afterdischarge induction.

Inhibition of $C O X-2$ during the latent phase, which follows status epilepticus, and is prodromal to spontaneous seizures onset, has given variable results. Either neuroprotection and decreased spontaneous seizures, or no major effects on neuropathology and various functional outcomes have been reported, depending on the anti-COX-2 treatment schedule and the severity of chemically or electrically induced status epilepticus in each of these studies.

mTOR inhibition by rapamycin has also given contrasting results since anti-epileptogenesis actions consisting of inhibition of sprouting and decreased chronic seizure frequency have been reported in kainate-treated rodents, while chronic epilepsy onset or severity was not affected in pilocarpine-treated animals.

\section{Blood Brain Barrier BBB Dysfunction as a Biomarker of Epilepsy}

Status epilepticus induced by kainate or pilocarpine in mice has been demonstrated to upregulate adhesion molecules, such as ICAM-1, VCAM-1 and E-and P-selectin, on endothelial cells of brain microvasculature. This phenomenon was also described following epileptifom activity induced by bicuculline in an in vitro guinea pig preparation. Leukocyte adhesion on inflamed brain endothelium was implicated in the vascular leakage during seizure activity in vivo, and the interference with this phenomenon after pilocarpine-induced status epilepticus reduced the frequency of spontaneous seizures in epileptic mice.

Potential Biomarkers in TBI (Traumatic Brain Injury)

Candidate biomarkers of TBI include serum or CSF levels

\begin{tabular}{|c|c|c|}
\hline Molecule & Biomaterial & Remarks \\
\hline S100B & Serum/CSF & $\begin{array}{l}\text { Levels correlate with injury severity after trauma } \\
\text { and have predictive value on neurological } \\
\text { outcome }\end{array}$ \\
\hline NSE & Serum & $\begin{array}{l}\text { Levels correlate with neurologic outcome after } \\
\text { trauma and reflect neuronal damage after SE }\end{array}$ \\
\hline GFAP & Serum/CSF & $\begin{array}{l}\text { Levels correlate with injury severity after trauma } \\
\text { and have predictive value on neurologic } \\
\text { outcome; increase in CSF correlates with } \\
\text { epileptogenesis stage in the kainic acid SE model }\end{array}$ \\
\hline UCHL1 & CSF & $\begin{array}{l}\text { Increase in CSF correlates with epileptogenesis in } \\
\text { the kainic acid model }\end{array}$ \\
\hline MBP & Serum & $\begin{array}{l}\text { Released in the course of brain trauma; } \\
\text { predictive value for epileptogenesis to be }\end{array}$ \\
\hline
\end{tabular}

of protein leaking from the brain, which may represent a distinct correlate of brain damage. Table 2

Table 2. Examples of Potential Biomarkers for Epileptogenesis in Cerebrospinal fluid (CSF) and Blood Serum

\section{MicroRNA Expression Profiling Indicates Biomarkers for Epilepsy}

Over the past seven years, several target studies and genome- wide miRNA expression profiling studies have identified changes to over 100 different miRNAs in epilepsy patients and animal models.

In our review we focused on four studies involving 295 human participants and rats' models have shown that miRNA 301a-3p was significantly dysregulated in Epilepsy with one study claiming that it had the best diagnostic value for Drug resistant epilepsy with $80.5 \%$ sensitivity and $81.2 \%$ specificity (Wang at el. 2015). Two studies involving 245 human participants have shown that miR-106b-5p was significantly dysregulated in Epilepsy with one study claiming that it had the best diagnostic value epilepsy with $80.3 \%$ sensitivity and $81.2 \%$ specificity (Wang at el. 2015). 